\title{
The Effect of "Big Maths for Little Kids" Curriculum on Mathematical Development of 61-72 Month- Old Children*
}

\author{
Meryem ÇELİK ${ }^{* *}$
}

\author{
Adalet KANDIR $^{* * *}$
}

Received: 14 December 2012

Accepted: 11 September 2013

\begin{abstract}
This study aimed to investigate the effect of "Big Math for Little Kids" curriculum on mathematical development of 61-72 month-old children attending kindergartens. This experimental study had a pre-test - post-test design. The sample of the study was composed of a total of 42 61-72 month-old children attending kindergartens of the randomly selected primary schools. In the study, "Progress in Maths 6 Test" was used to collect data. As a result of this study, it was found out that average Progress in Maths 6 Test scores of children in the experimental group were significantly higher than those of the ones in the control group.
\end{abstract}

Keywords: Mathematical development, mathematics at preschool level, mathematics curriculum

\section{Extended Abstract}

Purpose and Significance: The purpose of the current research was to investigate the effect of "Big Math for Little Kids" curriculum on mathematical development of 61-72 month-old children attending kindergartens.

Methods: This experimental study had a pre-test-post-test design. The population of the study consisted of 61-72 month-old children attending to kindergartens within primary schools under the Ministry of National Education in the city of Ankara in the educational year of 2010-2011. The sample comprised of a total of 42 children who were at the age of six $(n=21)$ both under the experimental group attending to GülenMuharremPakoğlu Primary School and $(n=21)$ the control group attending to HamdullahSuphi Primary School and who have not received math education before. In order to investigate the effect of the "Big Maths for Little Kids" curriculum on mathematical development of 61-72 month-old children, pre-test - post test control group design was used. To learn more about children and their families, "General Information Form" was used and "Progress in Maths 6 Test" developed by Clausen-May, Vappula and Ruddock (2004) and of which reliability check was done by Çelik and Kandır (2011) was used in order to determine mathematical development of children. Children in the experimental group had been offered the "Big Maths for Little Kids” curriculum for 14 weeks, five days a week. In the control group, only the preschool curriculum was implemented.

Results: For the analysis of the data, Mann-Whitney $U$ Test and Wilcoxon Signed Rank Test were used. Significant differences were found between mathematical development scores of children in the experimental and control group in favor of the experimental group $(p<.05)$. On the other hand, it was found that the difference between the post-test and

\footnotetext{
*This article was generated from the Ph.D thesis.

** Corresponding Author: Assist. Prof. Dr., Atatürk University, mtancelik@gmail.com

****Assoc. Prof. Dr., Gazi University, akandir@gazi.edu.tr
} 
retention-test scores of mathematical development of the children in the experimental group was not significant $(p>.05)$

Discussion and Conclusions: Depending on these findings, it was found out that the "Big Maths for Little Kids" curriculum was effective with mathematical development of children, and had a retentive impact. 


\section{1-72 Aylık Çocukların Matematik Gelişimine "Küçük Çocuklar İçin Büyük Matematik (Big Math for Little Kids)" Eğitim Programının Etkisi*}

\author{
Meryem ÇELIK ${ }^{* *}$
}

\author{
Adalet KANDIR ${ }^{* * *}$
}

Makale Gönderme Tarihi: 14 Aralık 2012

Makale Kabul Tarihi: 11 Eylül 2013

ÖZET: Bu araştırma, anasınıfına devam eden 61-72 aylık çocukların matematik gelişimine "Küçük Çocuklar için Büyük Matematik" programının etkisini incelemek amacıyla yapılmıştır. Araştırma deneme modelinde olup kontrol gruplu ön-test - son-test modeli uygulanmıştır. Araştırma örneklemini tesadüfî örnekleme ile seçilmiş iki ilköğretim okulunun anasınıfina devam eden 61-72 aylık toplam 42 çocuk oluşturmuştur. Çalışmada verilerin toplanmasında Matematik Gelişimi 6 testi kullanılmıştır. Araştırmanın sonucunda, deney grubundaki çocukların Matematik Gelişimi 6 Testi puan ortalamalarının kontrol grubundaki çocukların puan ortalamalarından anlamlı derecede daha yüksek olduğu bulunmuştur.

Anahtar Sözcükler: Matematik gelişimi, okul öncesi dönemde matematik, matematik eğitim programı

\section{Giriş}

Erken çocukluk yıllarında kazanılan davranışlar, bilgiler ve beceriler bireyin gelecekteki yaşamının temelini oluşturmaktadır. Bu dönemde çocuklar hızlı bir değişim ve gelişim içindedirler ve öğrenme hızları oldukça yüksektir (Cole \& Cole, 2001). Çocukların tüm gelişim alanlarında olduğu gibi matematik gelişimlerinin de temeli büyük oranda yaşamlarının ilk yıllarında atılmaktadır (Brewer, 2001; Clements \& Sarama, 2007a; Brown, Molfese, \& Molfese, 2008).

Yaşamın her alanında matematiğin olmasından dolayı matematiksel kavramlarla iç içe olan çocukların oyunlarında, birbirleriyle etkileşimlerinde, öyküler anlatmaya çalıştıklarında matematiğin birçok alanıyla ilgilendikleri ve hatta bundan büyük keyif aldıkları gözlenebilmektedir (Ginsburg, Greenes, \& Balfanz, 2003; Jackman, 2005). Erken çocukluk yıllarında çocuklar hangi kültüre ve ön yaşantılara sahip olursa olsunlar aynı tür matematik düşünceleri, stratejileri ve becerileri geliştirmektedirler (Ginsburg ve diğerleri, 2003). Araştırmacılar, bebeklerin ve çocukların, bir gün, matematik için kullanacakları yetenekleri nasıl geliştirdiklerini öğrenmenin çabası içindedirler (Jackman, 2005). Bu araştırmacıların öncülerinden olan Piaget'nin çocukların bilişsel gelişimi ile ilgili araştırmaları gelişimsel psikoloji ve eğitim alanında yıllarca en yaygın görüş olarak kabul edilmiştir. Piaget çalışmalarında, çocukların bilgiyi yalnızca yetişkinlerden almadığını bunun yerine dünyayı anlamak için kendi anlayış biçimlerini oluşturduklarını savunmuştur (Piaget, 1973, aktaran Ginsburg ve diğerleri, 2003).

Daha sonraki yıllarda araştırmacılar, Piaget'nin kuramından esinlenerek farklı araştırma desenleri ile çocukların bilişsel gelişimleri konusunda çalışmalarına devam etmişlerdir. $\mathrm{Bu}$ çalışmaların sonucunda, bebeklerin bile bazı temel matematik yeteneklerine sahip olduğu savı tartışılmaya başlanmıştır. Yaşamlarının ilk yılında bebeklerin nesnelerin şekillerini onu ağzına alarak veya ona dokunarak keşfedebildikleri, iki nesnelik bir grubun, üç nesnelik bir gruptan farklı olduğunu algılayabildikleri saptanmıştır. Benzer şekilde, erken yıllarda çocukların, küçük nesne grupları sunulduğunda, hangi grubun daha fazla olduğunu anlayabildikleri ve bir gruba nesne

\footnotetext{
*Bu makale doktora tezinden oluşturulmuştur.

** Sorumlu yazar: Yrd. Doç. Dr., Atatürk Üniversitesi, mtancelik@gmail.com

**** Doç. Dr., Gazi Üniversitesi, akandir@gazi.edu.tr
} 
eklendiğinde o grubun fazlalaştığını algılayabildikleri, toplama ve çıkarmanın temel ilkelerine sahip olabildikleri tespit edilmiştir. İki yaşındaki çocuğun iki parmağını göstererek iki yaşında olduğunu anlatmaya çalışması, dört yaşındaki çocuğun "bir, iki, üç, dört, beş, altı" diyerek sayması, beş yaşındaki çocuğun ise sayıların yanında şekiller ve biçimlerle ilgilenmesi, yaptığı binanın ne kadar büyük olduğunu anlatması, kuleleri temsil eden iki silindir ile bir kale yaparak ve üzerlerine üçgen bloklar koyarak üç boyutlu simetrik yapılar oluşturması matematik gelişiminin erken yıllarda görünür şekilde ortaya çıkmış olduğunun önemli kanıtlarından sayılmıştır (Ginsburg ve diğerleri, 2003; Jackman, 2005).

Günümüzdeki araştırmacılar ise erken çocukluk yıllarında çocukların matematiği öğrenmesi için günlük deneyimin yanı sıra içinde bulundukları çevrenin önemine de dikkat çekmektedirler çünkü çocuklar matematiği çevrelerindeki dikkat çeken ve dikkati etkileyen durumlarla bağlantılı olarak anlayabilmektedirler (Jackman, 2005).

Çocukların içinde bulundukları ilk çevreleri ev ortamıdır. Araştırma sonuçları, ailelerin ev ortamında matematiksel gelişim için yaptığı uygulamaların sıklığının ve çeşidinin çocuklarda matematiksel gelişimi desteklemede etkili olduğunu göstermektedir (Starkey, Klein, \& Wakeley, 2004; Young \& Loveridge, 2004). Ailenin eğitim durumunun, matematiğe olan bakış açılarının, evde çocuğa sunulan matematiksel etkinliklerin kalitesinin, karşılaştıkları problemleri çözmede onlara verilen desteğin çocukların matematik gelişimleri üzerinde önemli etkisinin bulunduğu kabul edilmektedir (Clements \& Sarama, 2007a).

Okulda ise eğitimcinin sosyal motivasyona dayalı ve bilişsel davranışların geliştirilebileceği bir sınıfta öğrenme ortamı oluşturma girişiminde bulunması önemli görülmektedir. Öğretmenlerin matematik dilini kullanmaları, çocukların matematiksel bilgileri gün boyunca ve program çerçevesinde kazanmalarına yardımcı olmaları gerekmektedir. Ayrıca öğretmenlerin, çocuklara birlikte çalışabilecekleri, tartışabilecekleri, çaba gösterebilecekleri, risk alabilecekleri, öğrenme ve problem çözmeye yönelik farklı yaklaşımlara saygı gösterebilecekleri, özgürlük sunan, destekleyici bir ortam oluşturmaya çalışmasının çocukların matematik gelişimi için gerekli olduğu düşünülmektedir (Geerens, 2004; Ginsburg \& diğerleri, 2003; Jackman, 2005; Kriova \& Bhargava, 2002).

Starkey ve diğerleri (2004) evde ya da okul öncesi eğitim kurumlarında çocukların matematik gelişimi için uygulanan etkinliklerin sistematik bir matematik programı ile zenginleştirilmesi gerektiğini vurgulamaktadırlar. Bu amaç için Avrupa ve Amerika'da okul öncesi yaş grubu çocuklarının tüm matematik gelişimlerini içeren ulusal matematik eğitim standartları ve bu standartların temel alındığı matematik eğitim programları geliştirildiği hâlde Türkiye'de böyle çalışmalar bulunmamaktadır. Bu amaç doğrultusunda yapılan çalışmada anasınıfına devam eden 61-72 aylık çocukların matematik gelişimine "Küçük Çocuklar için Büyük Matematik" eğitim programının (Big Math forLittle Kids) etkisi incelenmiştir.

\section{Yöntem}

\section{Örneklem}

Araştırmanın evrenini, Ankara il merkezindeki Milli Eğitim Bakanlığı'na bağlı ilköğretim okullarındaki anasınıflarına devam eden, normal gelişim gösteren 61-72 ay çocukları oluşturmuştur. Örneklemi Ankara il merkezinde tesadüfi örnekleme yöntemi ile seçilen iki ilköğretim okulunun anasınıfına devam eden 21'i deney grubunda, 21'i kontrol grubunda bulunan toplam 42 çocuk oluşturmuştur. 
Deney grubundaki çocukların \%52.3'ünün kı, \%47.7'sinin erkek ve kontrol grubundaki çocukların \%42.9'unun kı, \%57.1'inin erkek olduğu, deney grubundaki çocukların \%47.7'sinin ilk ve \%42.9'unun son çocuk, kontrol grubundaki çocukların \%66.7'sinin son ve \%33.3'ünün ilk çocuk olduğu, deney grubundaki çocukların $\% 47.7$ 'sinin ve kontrol grubundaki çocukların \%52.3'ünün iki çocuk olduğu, deney grubundaki çocukların \%47.7'sinin ve kontrol grubundaki çocukların \%52.3'ünün daha önce okul öncesi eğitim aldığı belirlenmiştir.

Deney grubundaki çocukların annelerinin \%61.9'unun ve kontrol grubundaki çocukların annelerinin \%47.7'sinin, hem deney hem de kontrol grubundaki çocukların babalarının \%52.3'ünün 30-39 yaş grubunda olduğu, deney grubundaki çocukların annelerinin \%57.2'sinin üniversite ve kontrol grubundaki çocukların annelerinin $\% 47.7$ 'sinin lise mezunu olduğu, deney grubundaki çocukların babalarının \%61.9'unun ve kontrol grubundaki çocukların babalarının \%52.3'ünün üniversite mezunu olduğu, hem deney hem de kontrol grubundaki çocukların annelerinin \%57.2'sinin ev hanımı olduğu, deney grubundaki çocukların babalarının \%47.7'sinin ve kontrol grubundaki çocukların babalarının \%52.3'ünün memur olduğu belirlenmiştir.

\section{Veri Toplama Araçları}

Araştırmada, çocuklar ve ailelerine ilişkin genel bilgileri toplamak amacıyla "Genel Bilgi Formu" kullanılmıştır. "Genel Bilgi Formu”nda çocuğun doğum tarihi, cinsiyeti, doğum sırası, kardeş sayısı, okul öncesi eğitim kurumuna gitme durumu, anne-babanın yaşı, anne-babanın öğrenim durumu, anne-babanın mesleği ve anne-babanın çalışma durumu ile ilgili sorular yer almaktadır. Çocukların matematik gelişimini değerlendirmek amacıyla Clausen-May, Vappula ve Ruddock (2004) tarafından geliştirilen ve Türkçe geçerlik ve güvenirliği Çelik ve Kandır (2011) tarafından yapılan "Matematik Gelişimi 6 (Progress in Maths 6) Testi” kullanılmıştır. Matematik Gelişimi 6 Testi, Mayıs 2004'te standardize edilmiştir. Standardizasyon örneğinin ortalama ham puanının 28 üzerinden 19.72 olduğu ve 5.10 standart sapmaya (SD) sahip olduğu, Cronbach Alfa güvenirliğinin de 0.84 olduğu bulunmuştur. Çelik ve Kandır (2011) tarafından Türkçeye uyarlaması yapılan "Matematik Gelişimi 6 Testi"ninyapılan güvenirlik analizi sonucunda Alpha korelasyonu .80 ve KR-20 ise 0.81 olarak bulunmuştur. Analiz sonuçlarına göre test-tekrar test korelasyonu .95 olarak belirlenmiştir.

"Matematik Gelişimi 6 Testi"nin orijinal formu 4-14 yaş arası çocuk grubunu kapsamakta ve 11 diziden oluşmaktadır. "Matematik Gelişimi 6 Testi"nde sorular, sayı, şekil, alan ve ölçümler, veri kullanma kategorilerine ayrılmıştır. Yine testte sorular, gerçekleri ve yöntemleri bilme, kavramları kullanma, günlük problemleri çözme, mantık yürütme kategorilerine de ayrılmaktadır. Test, altı yaşındaki ya da mevcut ders yılı içinde bu yaşta olacak çocuklara gruplar hâlinde uygulanmaktadır. Testte 24 soru bulunmaktadır ve test uygulaması yaklaşık 35 dakika sürmektedir.

\section{Programı \\ “Küçük Çocuklar İçin Büyük Matematik (Big Math ForLittle Kids)" Eğitim}

"Küçük Çocuklar İçin Büyük Matematik (Big Math ForLittle Kids)" eğitim program1, Ginsburg ve diğerleri (2003) tarafından geliştirilmiş ve New York, Massachusetts, Maryland, Texas, Wisconsin ve İngiltere'de 61-72 aylık çocuklara üç yıl süresince uygulanmıştır. "Küçük Çocuklar İçin Büyük Matematik" eğitim programı, okul öncesi dönemde 61-72 aylık çocukların matematik gelişimlerini desteklemeyi amaçlamaktadır. "Küçük Çocuklar İçin Büyük Matematik" eğitim programı; çocukların önyargılardan uzak ve istekle katılacağı, rakamlar, şekiller, biçimler ve mantık, 
değerlendirme, rakamlarla işlem yapma ve mekânsal ilişkiler olmak üzere altı alanda planlanan etkinlikler ile geliştirilmiştir.

"Küçük Çocuklar İçin Büyük Matematik" eğitim programının materyalleri şöyledir:

- Program Özeti: "Küçük Çocuklar İçin Büyük Matematik” eğitim programının temelleri, geliştirme süreci, kapsamı, materyallerin kullanımı, programın uygulanması, programın değerlendirilmesi hakkında bilgiler içermektedir.

- Eğitimci Kaynak Seti: Rakamlar Nelerdir? Nesnelerin Şekilleri, Daha Fazla Şekiller, Haydi Ölçelim, Rakamlarla Çalışma ve Etrafi Dolaşalım isimli tema kitapçıkları ve öğretim etkinlikleri, çocuklara kavramları uygulama ve becerileri geliştirme fursatı veren ve öğretim materyali oluşturmak için yeniden üretilebilen bölümler ve değerlendirme formları bulunmaktadır.

- Sınıf Öykü Kitapları: Her tema için hazırlanmış bir adet renkli öykü kitabı bulunmaktadır.

- Eve Götür Öykü Kitapları: Çocukların okulda kullandıktan sonra eve götürerek ailesiyle çalışmasına olanak sağlayan sınıf öykü kitaplarının siyah-beyaz versiyonudur.

\section{Veri Toplama ve Verilerin Analizi}

Deney ve kontrol grubundaki çocuklara ve ailelerine ilişkin Genel Bilgi Formu 14 Şubat 2011 tarihinde araştırmacı tarafından ailelere uygulanmıştır. Çocukların matematik gelişimlerini değerlendirmek amaciyla deney ve kontrol grubundaki çocuklara "Matematik Gelişimi 6 Testi" 15 Şubat 2011 tarihinde ön-test olarak uygulanmıştır. Okulda test uygulamasının uygun bir şekilde yapılabilmesi için rahat bir oturma düzeni ve sessiz bir sınıf düzenlemesi oluşturulmuştur. Testin uygulama süresi her grup için ortalama 35-40 dakika sürmüştür.

Ön testler uygulandiktan sonra 16 Şubat-18 Mayıs 2011 tarihleri arasında, deney grubuna "Küçük Çocuklar İçin Büyük Matematik" eğitim programı uygulanmıştır. "Küçük Çocuklar İçin Büyük Matematik" eğitim programı haftanın beş iş günü 40-60 dakika süre ile toplam 14 hafta araştırmacılar tarafından uygulanmıştır. Deney grubundaki çocuklara "Küçük Çocuklar İçin Büyük Matematik" eğitim programının uygulanmadığı süre zarfında Milli Eğitim Bakanlığı 36-72 aylık çocuklar için okul öncesi eğitim programına yönelik günlük eğitim programları sınıf öğretmenleri tarafından uygulanmıştır. Kontrol grubundaki çocuklar için Milli Eğitim Bakanlığı 36-72 aylık çocuklar için okul öncesi eğitim programı uygulamasına devam edilmiştir.

Araştırmacılar deney grubuna uygulanacak matematik eğitiminden önce eğitim ortamını her etkinlik için uygun bir şekilde düzenlemişlerdir. Daha önceden çocuk sayısı ya da grup sayısı kadar hazırlanmış materyaller araştırmacılar tarafindan sınıfa getirilmiştir. Eğitim programının uygulanması esnasında etkinliklerle ilgili fotoğraf ve video çekimleri yapılmıştır.

Eğitim programının uygulanması tamamlandıktan sonra deney ve kontrol gruplarına "Matematik Gelişimi 6 Testi" 18-23 Mayıs 2011 tarihleri arasında son test olarak uygulanmıştır. "Matematik Gelişimi 6 Testi" son testten yaklaşık bir ay sonra 14-15 Haziran 2011 tarihleri arasında deney grubundaki çocuklara tekrar uygulanmıştır.

Araştırmanın amacına yönelik toplanan veriler değerlendirilerek istatistiksel analizleri yapılmıştır. Araştırmaya dahil edilen deney ve kontrol gruplarındaki çocukların 
"Matematik Gelişimi 6 Testi"nden aldıkları ön test/son/izleme test puanları kayıt formlarına kaydedilmiştir. Kayıt formlarındaki bilgiler, bilgisayar ortamına aktarılarak Mann WhitneyU Testi ve Wilcoxon İşaretli Sıralar Testi ile analiz edilmiştir.

\section{Bulgular}

Anasınıfına devam eden 61-72 aylık çocukların matematik gelişiminde "Küçük Çocuklar İçin Büyük Matematik" programının etkili olup olmadığını ortaya koymak için yapılan araştırmanın sonuçları aşağıdaki gibi gruplandırılmıştır.

\section{Deney ve Kontrol Gruplarının Homojenliğine İlişkin Bulgular}

"Küçük Çocuklar İçin Büyük Matematik" programı uygulanmadan önce deney ve kontrol gruplarının aynı evrenden alınıp alınmadığını test etmek ve deney grubunu oluşturan çocuklarla, kontrol grubunu oluşturan çocukların Matematik Gelişimi 6 Testi puan ortalamaları arasında anlamlı düzeyde bir farklılaşma olup olmadığını belirlemek amacıyla her iki grupta yer alan çocukların ön-test puanlarının Mann-Whitney U Testi analiz sonuçları Tablo 1'de verilmiştir.

Tablo 1

Deney ve Kontrol Grubundaki Çocukların Matematik Gelişimi 6 Testi'nden Elde Edilen Ön-Test Puan Ortalamalarına IIlişkin Mann-Whitney U Testi Sonuçları

\begin{tabular}{lllcccc}
\hline & Grup & $n$ & Sira Ort. & Sira Top. & $U$ & $p$ \\
\cline { 2 - 6 } Matematik & Deney & 21 & 18.86 & 396.0 & 165.00 & .160 \\
& Kontrolsimi 6 & 21 & 24.14 & 507.0 & & \\
& Toplam & 42 & & & & \\
\hline
\end{tabular}

Tablo 1 incelendiğinde, deney grubuna ait ön-test puan ortalamaları ile kontrol grubuna ait ön-test puan ortalamaları arasında istatistiksel anlamlı bir fark bulunmadığı görülmektedir [ $U=165.00, p>.05]$.

Kontrollü ön-test - son-test modelli çalışmalarda deney ve kontrol gruplarına ait ön-test puanlarının olabildiğince birbirine yakın olması gerekmektedir (Kaptan, 1998). Tablo 1'de deney ve kontrol grubunun Matematik Gelişimi 6 Testi'nden aldıkları ön-test puanları incelendiğinde "Küçük Çocuklar İçin Büyük Matematik Programı"nı uygulamadan önce deney ve kontrol grubundaki çocukların benzer özellik gösterdiği söylenebilir.

\section{"Küçük Çocuklar İçin Büyük Matematik" Programının Çocukların Matematik Gelişimlerine Etkisine İlişkin Bulgular}

"Küçük Çocuklar İçin Büyük Matematik" programı deney grubuna uygulandıktan sonra "Küçük Çocuklar İçin Büyük Matematik" programının çocukların matematik gelişimlerine etkisini karşılaştırmak amacıyla deney grubunu oluşturan çocuklarla, kontrol grubunu oluşturan çocukların Matematik Gelişimi 6 Testi son-test puan ortalamaları arasında anlamlı düzeyde bir farklılaşma olup olmadığını belirlemek amacıyla Mann WhitneyU Testi analiz sonuçları Tablo 2'de verilmiştir. 
Tablo 2

Deney ve Kontrol Grubundaki Çocukların Matematik Gelişimi 6 Testi'nden Elde Edilen Son-Test Puan Ortalamalarına İlişkin Mann-Whitney U Testi Sonuçları

\begin{tabular}{llccccc}
\hline & Grup & $n$ & Sira Ort. & Sira Top. & U & $p$ \\
\cline { 2 - 7 } Matematik & Deney & 21 & 31.26 & 656.50 & 15.500 & $.000 *$ \\
& Kontrol & 21 & 11.74 & 246.50 & & \\
& Toplam & 42 & & & & \\
$* p<.05$ & & & & & &
\end{tabular}

Tablo 2'de görüldüğü gibi Matematik Gelişimi 6 Testi'nin genelinden alınan deney grubuna ait son-test puan ortalamaları ile kontrol grubuna ait son-test puan ortalamaları arasında istatistiksel olarak anlamlı bir fark bulunduğu saptanmıştır [ $U=15.500, p<.05]$. İstatistiksel olarak ortaya çıkan bu farkın deney grubuna ait son-test puanları lehine olduğu görülmektedir. Bu sonuca göre, deney grubundaki çocuklara uygulanan "Küçük Çocuklar İçin Büyük Matematik" programının çocukların matematik gelişimlerini pozitif yönde etkilediği söylenebilir.

\section{"Küçük Çocuklar İçin Büyük Matematik" Eŭitim Programının Çocukların Matematik Gelişimi Puan Ortalamalarına Etkisine İlişkin Bulgular}

Deney grubunu oluşturan çocukların Matematik Gelişimi 6 Testi ön-test puan ortalamaları ile "Küçük Çocuklar İçin Büyük Matematik" eğitim programından sonraki ölçümlerden elde edilen son-test puan ortalamaları arasındaki farkın anlamlı olup olmadığını test etmek amacıyla Wilcoxon İşaretli Sıralar Testi uygulanmış, sonuçlar Tablo 3 'te verilmiştir.

Tablo 3

Deney Grubunu Oluşturan Çocukların Matematik Gelişimi 6 Testi Ön-Test/Son-Test Puan Ortalamalarının Karşılaştırmasını Gösteren Wilcoxon İşaretli Stralar Testi Sonuçları

\begin{tabular}{|c|c|c|c|c|c|c|}
\hline \multirow{4}{*}{$\begin{array}{l}\text { Matematik } \\
\text { Gelişimi } 6\end{array}$} & $\begin{array}{l}\text { Ön test- } \\
\text { Son test }\end{array}$ & $n$ & Stra Ort. & Sira Top. & $z$ & $p$ \\
\hline & Negatif Sıra & 0 & 0.00 & 0.00 & -4.029 & $.000 *$ \\
\hline & Pozitif Sira & 21 & 11.00 & 231.00 & & \\
\hline & Esit & 0 & & & & \\
\hline
\end{tabular}

${ }^{*} p<.05$

Tablo 3 incelendiğinde, deney grubundaki çocukların Matematik Gelişimi 6 Testi ön-test ve son-test puan ortalamaları arasında anlamlı bir fark olduğu görülmektedir ( $\mathrm{z}=-$ 4.029, $p<.05)$. Fark puanlarının sıra ortalamaları ve toplamları dikkate alındığında gözlenen bu farkın pozitif sıralar yani, son test puanı lehine olduğu saptanmıştır.

"Küçük Çocuklar İçin Büyük Matematik" eğitim programı uygulanmayan kontrol grubundaki çocukların Matematik Gelişimi 6 Testi'nin araştırmacının kontrolü dışındaki değişkenlerden (gelişim, MEB 61-72 aylık çocuklar için eğitim programı vb.) etkilenip etkilenmediği test edilmiştir. Kontrol grubundaki çocukların Matematik Gelişimi 6 Testi 
ön-test ve son-test puan ortalamaları arasındaki fark Wilcoxon İşaretli Sıralar Testi ile sınanmıştır. Sınamalarla ilgili değerler Tablo 4'te verilmiştir.

Tablo 4

Kontrol Grubunu Oluşturan Çocukların Matematik Gelişimi 6 Testi Ön-test/Son-Test Puan Ortalamalarının Karşılaştırmasını Gösteren Wilcoxon Iş̧aretli Sıralar Testi Sonuçları

\begin{tabular}{llccccc}
\hline \multirow{2}{*}{$\begin{array}{l}\text { Matematik } \\
\text { Gelişimi 6 }\end{array}$} & \multicolumn{1}{c}{$\begin{array}{c}\text { Son test- } \\
\text { Sont }\end{array}$} & $n$ & Sira Ort. & Sira Top. & $z$ & $p$ \\
\cline { 2 - 7 } & Negatif Sıra & 6 & 6.67 & 40.00 & -1.745 & .081 \\
& Pozitif Sıra & 11 & 10.27 & 113.00 & & \\
& Eşit & 4 & & & & \\
\hline
\end{tabular}

Tablo 4'te görüldüğü gibi kontrol grubundaki çocukların Matematik Gelişimi 6 Testi'nden aldıkları ön-test ve son-test puanları arasında anlamlı bir fark olmadığı belirlenmiştir ( $z=-1.745, p>.05)$.

Deney ve kontrol grubundaki çocukların Matematik Gelişimi 6 Testi erişi puan farklarının ortalaması arasındaki fark, Mann-Whitney U Testi ile sınanmıştır. Sınamalarla ilgili değerler Tablo 5'te verilmiştir.

Tablo 5

Deney ve Kontrol Grubundaki Çocukların Matematik Gelişimi 6 Testi Erişi Puan Ortalamalarına İlişkin Mann-Whitney U Testi Sonuçları

\begin{tabular}{llccccc}
\hline & Grup & $n$ & Sira Ort. & Sira Top. & U & $p$ \\
\cline { 2 - 6 } Matematik & Deney & 21 & 32.11 & 672.00 & 0.00 & $.000^{*}$ \\
& Kontrol & 21 & 11.00 & 231.00 & & \\
& Toplam & 42 & & & & \\
\hline
\end{tabular}

${ }^{*} p<.05$

Tablo 5 incelendiğinde, deney ve kontrol grubundaki çocukların Matematik Gelişimi 6 Testi ön-test ve son-test puan farklarının ortalamaları arasında anlamlı bir fark olduğu görülmektedir $(U=0.00, p<.05)$. Fark puanlarının sira ortalamaları ve toplamları dikkate alındığında gözlenen bu farkın deney grubu lehine olduğu saptanmıştır.

\section{İlişkin Bulgular}

“Küçük Çocuklar İçin Büyük Matematik” Eğitim Programının Kalıcılığına

Deney grubu çocuklarına, "Küçük Çocuklar İçin Büyük Matematik" eğitim programı uygulandıktan hemen sonra (son-test) ve dört hafta sonra (izleme testi) Matematik Gelişimi 6 Testi uygulanmıştır. Çocuklara "Küçük Çocuklar İçin Büyük Matematik" eğitim programı uygulandıktan hemen sonra ve dört hafta sonra ölçülen Matematik Gelişimi 6 Testi puan ortalamaları arasında anlamlı bir farkın olup olmadığı Wilcoxon İşaretli Sıralar Testi ile sınanmıştır. Çocukların Matematik Gelişimi 6 Testi ile ilgili karşılaştırma bulguları Tablo 6'da verilmiştir. 
Tablo 6

Deney Grubu Çocukların İzleme Testi/ Son-Test Puan Ortalamalarına İlişkin Wilcoxon İsaretli Sıralar Testi Sonuçları

\begin{tabular}{|c|c|c|c|c|c|c|}
\hline \multirow{4}{*}{$\begin{array}{l}\text { Matematik } \\
\text { Gelişimi } 6\end{array}$} & $\begin{array}{c}\text { İzleme Test } \\
\text { Son test }\end{array}$ & $n$ & Sira Ort. & Stra Top. & $z$ & $p$ \\
\hline & Negatif Sira & 3 & 4.50 & 13.50 & -1.811 & .070 \\
\hline & Pozitif Sıra & 8 & 6.56 & 52.50 & & \\
\hline & Eşit & 10 & & & & \\
\hline
\end{tabular}

Tablo 6'da görüldüğü gibi deney grubundaki çocukların Matematik Gelişimi 6 Testi izleme testi/son-test puan ortalamaları arasında anlamlı bir farkın olmadığı belirlenmiştir ( $z=-1.811, p>.05)$.

\section{Sonuç ve Tartışma}

Deney grubuna ait ön-test puanları ile kontrol grubuna ait ön-test puan ortalamaları arasında istatistiksel olarak anlamlı bir fark bulunmadığı görülmektedir. Ancak deney grubuna ait son-test puanları ile kontrol grubuna ait son-test puan ortalamaları arasında deney grubunun lehine istatistiksel olarak anlamlı bir fark bulunmuştur. Bu sonuca göre, deney grubundaki çocuklara uygulanan "Küçük Çocuklar İçin Büyük Matematik" programının çocukların matematik gelişimlerini pozitif yönde etkilediği söylenebilir. Matematik eğitim programlarının değişik modellerinin çocukların matematik gelişimlerine katkı sağladığı görülmektedir. Sancak (2003), okul öncesi eğitim kurumlarına devam eden altı yaş çocuklarına sayı (1'den 10'a kadar) ve şekil (kare, daire, üçgen, dikdörtgen) kavramlarını kazandırmada bilgisayar destekli eğitim ve geleneksel eğitim yönteminin etkiliğini karşılaştırmayı amaçlamıştır. Deney grubuna bilgisayar destekli eğitim, kontrol grubuna da geleneksel eğitim yöntemi ile şekil ve sayı kavramı eğitimi verilmiştir. Araştırma sonucunda, bilgisayar destekli eğitim alan grubun geleneksel eğitim yöntemi ile eğitim alan gruba göre daha başarılı olduğu belirlenmiştir. Starkey ve diğerleri (2004), geliştirdikleri okul öncesi matematik müfredatını içeren matematik müdahale programının düşük ve orta gelirli ailelerin anaokuluna giden çocuklarının matematik gelişimine etkisini ve bu çocukların matematik gelişimlerini kapsamlı bir şekilde değerlendirmeyi amaçlamışlardır. Araştırmanın sonucunda, matematik eğitim programı her iki sosyoekonomik düzeydeki çocukların matematik bilgisini önemli düzeyde arttırmıştır. Düşük gelirli ailelerin çocuklarının başlangıç düzeylerine göre daha fazla başarı gösterdikleri ortaya çıkmıştır. Kaufmann, Delazer, Pohl, Semenza ve Dowker (2005), çocuklarda sayı ve işlemler gelişimini desteklemeye yönelik hazırladıkları programın etkisini ortaya koymak amacıyla deneysel çalışma yapmışlardır. Araştırma sonucunda, deney grubunun kontrol grubundan daha başarılı ve programın etkili olduğu bulunmuştur. Pagani, Jalbert ve Girard (2006), aritmetiksel işaretlerle zenginleştirilmiş iki programı (Montreal School Commission ve Rightstart Program) okul öncesi dönemde düşük gelirli ailelerin çocukların sayı bilgisine etkisi olup olmadığını incelemek amacıyla iki bölüm halinde uygulamışlardır. 1997-1998 ve 1998-1999 yılları arasında çocuklar ilk yıl MSC (Montreal School Comission) eğitimi almışlar, ikinci yıl ise çocukların \%44'ü bu programa ek olarak Rightstart programına tabi tutulmuşlardır. Uygulamanın sonunda yeni bir grupla 20002001 eğitim-öğretim yılında ikinci bir araştırma yapılmıştır. Anasınıfındaki uygulamaların kesin olmayan sonuçlar verdiği söylense de anaokulunda uygulanan programın daha sonraki aritmetik öğrenimi için çocukların yeteneklerine olumlu etki ettiği görülmüştür. 
Uygulanan matematik eğitimi programının uygulanabilir ve başarılı olduğu tespit edilmiştir. Clements ve Sarama (2007b), yaptıkları çalışmada anaokulundan ana sınıfina kadar çocukların matematik becerilerini geliştirmek için hazırladıkları yazılım programının etkililiğini ortaya koymayı amaçlamışlardır. Deney ve kontrol grubu eğitim-öğretim yılı başında ve sonunda değerlendirilmiştir. Deney grubuna yazılım programı uygulanmıştır. Yapılan ön-test ve son-test değerlendirmesi sonucunda deney grubundaki çocukların puanlarının kontrol grubundaki çocukların puanlarından önemli düzeyde yüksek olduğu bulunmuştur. Bu sonuçlar uygulanan matematik eğitimi programının çocukların matematik becerilerini desteklemede güçlü bir etkiye sahip olduğunu göstermiştir. Chard, Baker, Clarke, Jungjohann, Davis ve Smolkowski (2008), anasınıfı için oluşturdukları matematik programının (Early Learning in Mathematics Program) uygulanabilirliğini ortaya koymak amacıyla bir çalışma gerçekleştirmişlerdir. Deney grubunda olan çocuklara (Early Learning in Mathematics Program) program eğitim-öğretim y1lı boyunca uygulanmıştır. Deney grubunda olan çocukların son-test puanları kontrol grubunda olan çocuklardan daha yüksek bulunmuştur.

Yapılan araştırma sonucunda elde edilen bulgular ile yukarıda sunulan araştırmaların sonuçları arasında, çocukların matematik başarılarını artırmada etkili olması yönünden bir paralellik olduğu gözlenmektedir. Buna göre, "Küçük Çocuklar İçin Büyük Matematik" eğitim programının uygulandığı deney grubundaki çocuklar anlamlı düzeyde $(p<.05)$ başarı göstermişlerdir. Çocuk merkezli olması, çocukların ilgisini çekmesi, onlara matematikteki temel konuları derinlemesine, sistematik ve siralı olarak incelemelerini sağlayacak uygulama ve tekrar yapabilecekleri eğitim ortamları sunması, bir eğitimci rehberliğinde matematiği eğlenerek, oynayarak ve günlük yaşam etkinlikleri ile bütünleştirerek öğrenmelerini sağlayacak etkinliklerin yer alması, "aile mektubu", "eve götür oyunu" ve "eve götür öykü kitabı" gibi etkinliklerle aileyi de eğitimin içine alarak okulda verilen eğitimin evde pekiştirilmesini sağlaması açısından "Küçük Çocuklar İçin Büyük Matematik" eğitim programının deney grubundaki çocukların bu başarıyı elde etmelerinde etkili olduğu düşünülebilir. Kontrol grubunda ise uygulanan MEB 36-72 aylık çocuklar için okul öncesi eğitim programında tüm matematik becerilerine yönelik amaç ve kazanımlar yer almasına rağmen öğretmenlerin uygulamalarında geleneksel anlayışla sayı ve geometrik şekle dayalı etkinliklere daha çok yer verdikleri; işlemler, birebir benzerlik, parça-bütün ilişkisi, karşılaştırma, gruplama, sınıflama, sıralama, model alma, uzamsal düşünme, ölçme, veri analizi ve grafik olan diğer matematik becerilerini yeterince desteklemedikleri gözlenmektedir. Oysa çocukların tüm matematik becerilerinin aynı anda desteklenmesi son derece önemlidir ve günlük eğitim programında yer alan tüm etkinliklerin matematik etkinlikleri ile ilişkilendirilerek bütünleştirilmesi gereklidir. "Küçük Çocuklar İçin Büyük Matematik" eğitim programının bu özellikleri içermesi deney grubu lehine anlamlı düzeyde $(p<.05)$ farklılık çıkmasının nedeni olabilir.

Çocukların matematik başarılarını artırmada erken dönemde planlı, programlı ve araştırma temelli matematik eğitim programı modelleri ile matematik eğitimi verilmesi önemlidir. Clements (1983), okul öncesi çocuklara mantıksal işlemler ve rasyonel sayma stratejilerini kapsayan sayı kavramlarının gelişimi üzerinde iki farklı eğitim programı uygulamış ve aralarında fark olup olmadığını incelemiştir. Araştırmada deney gruplarından birine sınıflandırma ve sıralama becerileri (mantıksal yapılar) üzerine eğitim verilirken diğer deney grubuna rasyonel sayma stratejileri ve diğer sayı becerileri (beceri birleşimi) üzerine eğitim verilmiştir. Değerlendirme sonuçları incelendiğinde; her iki deney grubunun, hem sayı kavramlarında hem de mantıksal işlemlerde kontrol grubundan anlamlı düzeyde yüksek performans gösterdiği bulunmuştur. Ayrıca, deney grupları arasında da sayı kavramları testinde "birleşik sayı becerileri” eğitiminin verildiği grubun lehine anlamlı 
farklılıklar görülmüştür. Dere (2000), okul öncesi eğitim kurumlarına devam eden alt sosyo-ekonomik düzeydeki altı yaş çocuklarına bazı matematik kavramlarını kazandırmada yapılandırılmış ve geleneksel yöntemlerin etkililiğini karşılaştırmıştır. İki deney ve iki kontrol grubu oluşturulmuştur. Deney gruplarına yapılandırılmış ve geleneksel yöntemle grup oyunları, okuma-yazmaya hazırlık çalışmaları ve masa etkinlikleri kullanılarak geometrik şekil ve sayı kavramı eğitimi verilmiştir. Yapılan ön-test ve son-test sonucunda yapılandırılmış yöntem uygulanan çocukların puanlarında geleneksel yöntem ve kontrol grubundaki çocukların puanlarına oranla daha fazla artış olduğu saptanmıştır. Sophian (2004), çocukların gelecekte karşılaşacakları matematik öğrenme çeşitlerine kavramsal olarak hazırlanmalarının gerekli olduğu düşüncesinden hareketle deneysel matematik programı hazırlamıştır. İki kontrol grubu oluşturulmuş, uygulanan programın etkililiğini değerlendirmek için eğitim yılının başında ve sonunda olmak üzere çocuklara ve iki karşılaştırma grubuna ön-test ve son-test uygulanmıştır. Yapılan değerlendirme sonuçlarında uygulanan programın çocukların matematik gelişimlerini anlamlı düzeyde hızlandırdığı bulunmuştur. Yılmaz-Bolat ve Dikici-Sığırtmaç (2006), alt sosyo-ekonomik bölgedeki üç ilköğretim okulunun anasınıfına giden altı yaş çocuklarının sayı ve işlem kavramlarını kazanmalarında müzikli oyun etkinliklerinin etkisini incelemişlerdir. Araştırma sonucunda, sayı ve işlem kavramı açısından, deney grubu ile kontrol grupları arasında deney grubu lehine istatistiksel olarak anlamlı bir farklılık olduğu bulunmuştur. Baroody, Eiland ve Thompson (2009), risk altındaki okul öncesi çocuklarında sayı sezgisini geliştirmek için uyguladıkları okul öncesi sayı sezgisi programının etkililiğini değerlendirmişlerdir. Çalışma iki aşamada gerçekleştirilmiştir. Birinci aşamada çocuklara manipülatif ve oyun temelli olan esas program uygulanmıştır. İkinci aşamada ise dört farklı bilgisayar destekli durum içeren zihinsel-aritmetik öğrenme yazılım programı uygulanmıştır. Programın etkililiğini değerlendirmek için yapılan ön-test ve son-test ölçümleri sonucunda, programın çocukların matematik başarısını yüksek oranda artırdığı ortaya çıkmıştır. Anderson, Anderson ve Shapiro (2005), ailelerin ve çocukların matematik kavramları ve sözcükleri anlama ve açıklamada öykü kitaplarının etkisini ortaya koymak amacıyla yaptıkları çalışma sonucunda, ailelerin ve çocukların matematiksel kavram ve sözcüklere dikkatlerini çekmek için öykü okumanın önemli bir etkiye sahip olduğunu bulmuştur. Van Den Heuvel-Panhuizen ve Van Den Boogaard (2009), resimli kitapların beş-altı yaş çocukların matematik öğrenmeleri üzerindeki etkisini ortaya koymak amacıyla geometri, grafik ve ölçümü ele alan üç farklı resimli kitabı araştırmalarında kullanmışlardır. Araştırmada kaliteli olan resimli kitapların çocukların matematik öğrenmelerinde etkili olduğu sonucuna ulaşılmıştır. Araştırmada "Küçük Çocuklar İçin Büyük Matematik" eğitim programı içinde uygulanan öykü etkinliklerinin de çocuklarda görülen başarıdaki artış1 etkilediği düşünülmektedir.

Araştırmada deney grubunu oluşturan çocukların Matematik Gelişimi 6 Testi öntest - son-test puan ortalamalarında anlamlı düzeyde fark olduğu görülmüştür. Elde edilen bulgular ile yukarıda sunulan araştırmaların sonuçları arasında çocukların matematik başarılarını artırmada erken dönemde planlı, programlı ve araştırma temelli matematik eğitim programı modelleri ile matematik eğitimi verilmesinin etkili olması yönünden bir paralellik olduğu gözlenmektedir. Araştırmada deney grubuna uygulanan "Küçük Çocuklar İçin Büyük Matematik" programının matematiği günlük etkinlikler ve diğer akademik alanlarla (oyun, drama, okuma-yazmaya hazırlık, müzik, öykü vb.) birleştirmesi, çocukları bir bütün olarak ele alması (sosyal davranış, motivasyon, bilişsel esneklik, fiziksel ve algısal beceriler vb.), iyi bir öğretimin çocukların öğrendiği şeylerin hassas bir şekilde değerlendirilmesine dayandığı düşüncesiyle uygulama sürecinde çocukların matematik gelişimlerinin tek tek ve birçok teknikle değerlendirilmesine önem vermesi, 
yapılan değerlendirmeler sonucunda eğitimciye çocuklara nasıl yardım edileceği konusunda yönlendirmeler yapması gibi özellikleri içermesi deney grubundaki çocuklarda Matematik Gelişimi 6 Testi puanlarının son-test lehine istatistiksel olarak anlamlı $(p<.05)$ çıkmasının nedeni olabilir.

Araştırmadan elde edilen bulgularda kontrol grubunun ön-test ve son-test puanları arasında anlamlı fark bulunmamıştır. Türkmenoğlu (2005), okul öncesi dönemdeki çocuklara uygulanan 32 günlük "Oyun Yoluyla Matematik Kavramlarını Kazandırma Programı"nın matematik gelişimine etkisini incelemiştir. Deney grubuna matematik kavramları oyun yöntemiyle verilmiş, kontrol grubu ise mevcut okul öncesi programına devam etmiştir. Araştırma sonucunda, kontrol grubunun ön-test - son-test puan ortalamaları arasında anlamlı bir farklılık bulunmamıştır. Elde edilen bulguların, kontrol grubunun ön-test - son-test puanları arasındaki farkın anlamlı olmaması yönünden Türkmenoğlu (2005)'in yaptı̆ğ araştırmanın bulguları ile örtüştügü söylenebilir. Kontrol grubu çocuklarına MEB 36-72 aylık çocuklar için okul öncesi eğitim programı anasınıfı öğretmenleri tarafindan uygulanmıștır. Çocukların matematik becerilerinin gelișimi okulda öğretmenlerin onlara sunduğu öğrenme yaşantıları ile yakından ilişkilidir. Kontrol grubundaki çocukların matematik gelişimini değerlendiren ön-test - son-test puanlarının farklılaşmaması, öğretmenlerin çocukların matematik gelişimleri için gerekli tüm matematik becerilerini dengeli ve sistematik bir şekilde uygulayamamalarından, sınıflarda çocukların matematik gelişimlerini destekleyecek ve algılarını artıracak yeterli donanıma sahip eğitim ortamı sunamamalarından, çocukları süreç içerisinde objektif olarak değerlendirmeye gerekli önemi verememelerinden ve daha çok geleneksel öğretim yaklaşımlarını kullanmalarından kaynaklanmış olabilir.

Araştırmada deney ve kontrol grubundaki çocukların Matematik Gelişimi 6 Testi erişi puan ortalamalarına ilişkin Mann WhitneyU Testi sonuçlarına bakıldığında deney grubu lehine anlamlı bir farkın olduğu saptanmıştır. Matematik eğitim programı modellerinin çocukların matematik gelişimlerine olumlu etkisi birçok araştırma sonucunda görülmüştür. Starkey ve Klein (2000), düşük gelirli ebeveynlere gerekli eğitim sağlandığında çocuklarının gelişimini desteklemede istekli olacakları düşüncesinden hareketle çocukların matematik gelişimi için ebeveyn desteğini artırmak amacıyla bir araştırma yapmışlardır. Araştırma, iki aşamada gerçekleştirilmiştir. Birinci aşamada Afrika kökenli Head Start aileleri ve çocukları deney ve kontrol grubuna ayrılmış ve deney grubunda olan ebeveyn ve çocuklarına matematik programı uygulamışlardır. İstatistiksel sonuçlar, yapılan uygulamanın çocukların matematik gelişimini olumlu yönde etkilediğini göstermiştir. İkinci aşamada Latin kökenli Head Start aileleri ve çocukları deney ve kontrol grubuna ayrılmış ve birinci aşamadaki gibi uygulamalar yapılmıştır. İstatistiksel sonuçlar, yapılan uygulamanın çocukların matematik gelişimini olumlu yönde etkilediğini göstermiştir. Chao, Stigler ve Woodward(2000), anaokulu çocuklarının sayı kavramını öğrenmesi üzerine yaptıkları çalışmada iki tür materyal kullanmışlardır. Kullanılan materyallerden biri kiremit parçaları, diğeri ise sayının gösterilmesi için çeşitli yapılardaki nesnelerdir. Çalışma sonucunda iki farklı materyalin öğrenme üzerinde farklı etkilerinin olduğu bulunmuştur. Sayısal işlemler düzeyinde yapılandırılmış materyaller, çocukların parmak içermeyen stratejileri seçmelerini kolaylaştırmış ve parmak stratejisini kullananlar için yanıt süresini kısaltmıştır. İkinci gruptaki materyaller, parmak stratejilerini kullanan çocukların yetkinliğini artırırken, parmak stratejilerini kullanmayan çocuklar için böyle bir etki yaratmamıştır. Mulligan, Mitchelmore, Kemp, Marston ve Highfield (2008), "Örüntü ve Biçim Oluşturma Matematik Farkındalı Programı"nın (PatternandStructureMathematicsAwareness Program-PASMAP) etkililiğini ortaya koymak amacıyla yaptıkları çalışma soncunda uygulamaya katılan bütün çocuklarda 
önemli düzeyde puan artışı gözlemlemişler ve programın etkili olduğunu ortaya koymuşlardır. Casey, Andrews, Schindler, Kersh, Samper ve Copley (2008), yaratıcılığı kullanarak bloklarla çalışmanın anasınıfı çocuklarının uzamsal akıl yürütme becerilerini geliştirmedeki etkisini incelemişlerdir. Çalışmada, Sayı, Veri ve Uzay Araştırmaları (Investigations in Number, Data, and Space) serisi ve Her Gün Matematik (EverydayMathematics) serisi matematik programları uygulanmıştır. Deney gruplarından birine hem öykü hem de bloklarla yapacağı etkinlikler verilmiş, diğer deney grubundan ise aynı etkinlikleri sadece bloklarla yapmaları istenmiştir. Ön-test ve son-test değerlendirme sonuçları deney gruplarının kontrol grubundan uzamsal akıl yürütmede daha başarılı olduklarını göstermiştir. İki deney grubu karşılaştırıldığında ise uygulamanın hem öykü hem bloklarla yapıldığı deney grubun daha başarılı olduğu görülmüştür. Warren ve Devries (2009), matematiği anlama becerilerini tespit etmek amacıyla başlattıkları çalışmada uygulamaların matematik dilini ve gelişimini desteklediğini göstermişlerdir. Poland, Van Oers ve Terwel (2009), çocuk eğitiminde şemaların önemini ve çocuklara şemasal etkinliklerle öğretim yapılıp yapılamayacağını ortaya koymak amacıyla yaptıkları çalışma sonucunda, deney grubunda olan çocukların kontrol grubundakilerden daha fazla başarılı olduğunu bulmuşlardır. Araştırmacılar bu bulgulara dayanarak şemalarla yapılan eğitimin, çocukların daha sonraki yıllarda matematik öğrenmelerini olumlu yönde etkileyeceğini belirtmişlerdir.

Araştırmadan elde edilen bulgular ile yukarıda sunulan araştırmaların sonuçları matematik eğitim programı modellerinin çocukların matematik gelişimlerini desteklemede olumlu etkiye sahip olması açısından örtüşmektedir. Buna göre, "Küçük Çocuklar Için Büyük Matematik" eğitim programının uygulandığı deney grubundaki çocuklar anlamlı düzeyde $(p<.05)$ başarı göstermişlerdir. "Küçük Çocuklar İçin Büyük Matematik" eğitim programının; planlı bir şekilde çocukların matematik eğitim gereksinimlerini karşılamış olması, matematiksel kavramları uygulama ve becerileri geliştirme firsatı veren özel tasarlanmış materyallerle aktif fiziksel katılım sunması, bireysel, küçük grup ve büyük grup etkinliklerine dengeli şekilde yer vermesi, eğlenceli matematik etkinliklerini içermesi yönünden çocukların ilgisini çekmesi ve daha uzun süre tutmada etkili olması, farklı öğretim yöntemleri ve teknikleri kullanmayı içermesi, aileyi bu sürece dahil etmesi çalışmadaki matematik gelişiminin nedenleri olabilir.

"Küçük Çocuklar İçin Büyük Matematik" eğitim programının kalıcılığını değerlendirmek amacıyla son testten dört hafta sonra deney grubundaki çocuklar, tekrar test edilmiştir. Deney grubundaki çocukların Matematik Gelişimi 6 Testi izleme testi son-test puan ortalamaları arasında anlamlı bir farkın olmadığı belirlenmiştir ( $p>.05)$. Elde edilen sonuç matematik eğitim programı uygulayan ve kalıcılığı test eden birçok araştırma sonucu ile örtüşmektedir. Van De Rijt ve Van Luıt (1998), dört-yedi yaş grubu çocuklar için hazırladıkları matematik eğitim programının (TheAdditionalEarlyMathematics) etkililiğini ortaya koymayı amaçlayan deneysel araştırmalarında ön-test, son-test ve izleme testi yapmışlar ve yapılan uygulama sonucunda deney grubunun ön-test ve son-test puanları arasında önemli düzeyde farklılıklar bulmuşlardır. Yedi ay sonra yapılan izleme testi sonucunda ise programın kalıcı bir etkiye sahip olduğunu belirlemişlerdir. Young ve Loveridge (2004), çocukların sayı becerilerini geliştirmek üzere oyunlar ve sayı kitaplarının kullanıldığı bir programın etkilerini inceledikleri çalışmalarında, deney grubundaki çocukların lehine oldukça yüksek oranda anlamlı bir fark kaydetmişlerdir. Çalışma sonucunda okul öncesi dönemde çocukların sayı bilgilerinin güçlendirilmesinin uzun dönemde çocukların matematik eğitimine büyük destek sağladığını ortaya koymuşlardır. Ayrıca, programdan elde edilen faydanın bir yıl boyunca sürdüğü de belirlenmiştir. Aunio ve Van Luit (2005) okul öncesi çocukların sayı algısını müdahale 
programıyla geliştirmek amacıyla yaptıkları çalışmada, ön-test ve son-test bulgularını programın uygulanmasından hemen sonra karşılaştırmışlardır. Deney grubundaki çocukların sayı algı performanslarının anlamlı ölçüde yükseldiğini, fakat gruplar arasındaki farkın altı ay sonra azaldığını belirlemişlerdir.

"Küçük Çocuklar İçin Büyük Matematik" eğitim programının kalıcılığına ilişkin bulguların, yukarıdaki araştırmalarda uygulanan matematik eğitim programlarının etkisinin zamana bağlı olarak azaldığı, ancak istatistiksel olarak anlamlı olmadığ sonuçlarıyla örtüştüğü söylenebilir. Araştırmada izleme süresi dört hafta olarak alınmış ve izleme testinden elde edilen matematik gelişimi puan ortalaması göreli olarak son-test puan ortalamalarından daha düşük bulunmasına rağmen anlamlı düzeyde fark ( $p>0.05)$ bulunamamıştır. İzleme testi ile son-test karşılaştırıldığında "Küçük Çocuklar İçin Büyük Matematik" eğitim programının etkisinin zaman içinde azaldığı görülmektedir.

Yurtdışında yapılmış araştırmalarda izleme testinin altı, yedi ay sonraki etkisine ilişkin sonuçlar verilmiştir. Türkiye'de de çocukların matematik gelişimi ile ilgili çeşitli araştırmalar yapılmıştır (Alabay, 2006; Canoğlu, 2007; Dikici, 2002; İrkörücü, 2006; Türkmenoğlu, 2005). Ancak bu araştırmalarda uzun süreli izleme çalışmaları yapılmadığından araştırma sonuçlarıyla karşılaştırma yapılamamıştır.

Buna göre, "Küçük Çocuklar İçin Büyük Matematik" eğitim programının etkisinin istatistiksel olarak anlamlı olmamakla birlikte zaman içinde azaldığ 1 doğal bir sonuç olarak yorumlanabilir.

\section{Öneriler}

Araştırmadan elde edilen veriler ışığında aşağıdaki öneriler sunulmuştur:

- "Küçük Çocuklar İçin Büyük Matematik" eğitim programının etkililiğini test etmek için pilot okullar seçilerek daha geniş örneklem grubunun bu eğitimden yararlanması sağlanabilir ve sonuçları test edilebilir.

- “Küçük Çocuklar İçin Büyük Matematik” eğitim programı farklı sosyo-kültürel düzeydeki çocukların devam ettiği okul öncesi eğitim kurumlarında uygulanabilir ve elde edilen verilerle karşılaştırmalar yapılabilir.

- Okul öncesi eğitim kurumlarında "Küçük Çocuklar İçin Büyük Matematik" eğitim programı ve materyallerinin kullanımına ilişkin eğitim seminerleri düzenlenerek öğretmenlerin kullanımına sunulabilir.

- “Küçük Çocuklar İçin Büyük Matematik” eğitim programının etkisi yaş, bilişsel gelişim, anne-baba öğrenim düzeyi, sosyo-ekonomik düzey, okul öncesi eğitim kurumlarına devam etme durumu gibi farklı değişkenler açısından araştırılabilir.

- “Küçük Çocuklar İçin Büyük Matematik” eğitim programının kalıcılığı, eğitim programının sonunda 3, 6 ve 12 aylık dönemlerle izlenebilir.

- “Küçük Çocuklar İçin Büyük Matematik" eğitim programının esaslarının ve etkinliklerinin, MEB 36-72 aylık çocuklar için okul öncesi eğitim programı ile kaynaştırılması için Milli Eğitim Bakanlığı Okul Öncesi Eğitimi Genel Müdürlüğü ile işbirliği yapılabilir.

- "Küçük Çocuklar İçin Büyük Matematik" eğitim programının yöntem ve teknikleri ilköğretim birinci sınıf öğretmenleriyle paylaşılabilir, işbirliği yapılabilir ve ilköğretim birinci sınıf çocuklarına uygulanarak yeni araştırmalar yapılabilir. 


\section{Kaynakça}

Alabay, E. (2006). Altı yaş okul öncesi dönemi çocuklarına bilgisayar destekli matematiksel kavramların ögretimi (Yayımlanmamış yüksek lisans tezi). Selçuk Üniversitesi, Konya.

Anderson, A., Anderson, J., \& Shapiro, J. (2005). Supporting multiple literacies: Parents’ and children's mathematical talk within storybook reading. Mathematics Education Research Journal, 16(3), 5-26.

Aunio, P. H. J., \& Van Luit, J. (2005). Mathematical thinking intervention programmes for preschool children with normal and low number sense. European Journal of Special Needs Education, 20(2), 131-146.

Baroody, A. J., Eiland, M., \& Thompson, B. (2009). Fostering at-risk preschoolers' number sense. Early Education \& Development, 20(1), 80-128.

Brewer, J. A. (2001). Introduction to early childhood education. Boston : Allyn \& Bacon.

Brown, E. T., Molfese, V. J., \& Molfese, P. (2008). Preschool student learning in literacy and mathematics: Impact of teacher experience, qualifications, and beliefs on an atrisk sample. Journal of Education for Students Placed at Risk, 13, 106-126.

Canoğlu, M. (2007). Okul öncesi eğitim kurumlarına devam eden 6 yaş grubu çocuklarda proje tabanlı ögrenmenin sezgisel matematik becerilerine etkisi (Yayımlanmamış yüksek lisans tezi).Abant İzzet Baysal Üniversitesi, Bolu.

Casey, B. M., Andrews, N., Schindler, H., Kersh, J. E., Samper, A., \& Copley, J. (2008). The development of spatial skills through interventions involving block building activities. Cognition and Instruction, 26, 269-309.

Chao, S. C., Stigler, J. W., \& Woodward, J. A. (2000). The effects of physical materials on kindergartners' learning of number concepts. Cognition and Instruction, 18, 285-316.

Chard, D. F., Baker, S. K., Clarke, B., Jungjohann, K., Davis, K., \&Smolkowski, K. (2008). Preventing early mathematics difficulties: The feasibility of a rigorous kindergarten mathematics curriculum. Learning Disability Quarterly, 31, 11-20.

Clements, D. H. (1983, April 21-24). Training effects on the development and generalization of Piagetian logical operations and counting strategies.Paper presented at the Biennial Meeting of the Society for Research in Child Development, Early Childhood Education, Kent State University, Ohio: US

Clements, D. H. \& Sarama, S. (2007a). Early childhood mathematics learning. In F. K. Lester (Ed.), Second handbook of research on mathematics teaching and learning (pp. 461-556). Charlotte: Information Age Publishing.

Clements, D. H. \& Sarama, J. (2007b). Effects of a preschool mathematics curriculum: Summary research on the buildingblocks project. Journal for Research in Mathematics Education, 3(2), 136-163.

Cole, M., \& Cole, S. (2001). The development of children. San Diego: WorthPublishers.

Çelik, M., \& Kandır, A. (2011). Matematik Gelişimi 6 Testi (Progress in Maths 6) nin 6077 aylar arasında olan çocuklar için geçerlik ve güvenirlik çalışması. Kuramsal Eğitimbilim Dergisi, 4(1), 146-153.

Dere, H. (2000). Okul öncesi eğitim kurumlarına devam eden 6 yaş çocuklarına bazı matematik kavramlarını kazandırmada yapılandırılmış ve geleneksel yöntemlerin karşılaştırılması (Yayımlanmamış yüksek lisans tezi). Gazi Üniversitesi, Ankara.

Dikici, A. (2002). Orff tekniği ile verilen müzik ĕgitiminin matematik yeteneğine etkisinin incelenmesi (Yayımlanmamış doktora tezi).Ankara Üniversitesi, Ankara. 
Ginsburg, H. P., Greenes, C., \& Balfanz, R. (2003). Big math for little kids. "Program Overview” Pasippany, NJ: Pearson Learning Group.

İrkörücü, S. (2006). Okul öncesi eğitim kurumuna devam eden 6 yaşındaki çocuklara uygulanan ev odakl matematiksel destek programının çocukların matematiksel kavram edinimine etkisinin incelenmesi (Yayımlanmamış yüksek lisans tezi).Gazi Üniversitesi, Ankara.

Jackman, L. H. (2005). Early education curriculum: A child's connection to the world (3rd ed.). NY: ThomsonDelmar Learning.

Kaptan, S. (1998). Bilimsel araştırma ve istatistik teknikleri (11. baskı). Ankara: Tekışık Web Ofset.

Kaufmann, L., Delazer, M., Pohl, R., Semenza, C., \& Dowker, A. (2005). Effects of a specificnumeracyeducational program in kindergartenchildren: A pilot study. Educational Research and Evaluation, 11(5), 405-431.

Pagani, L. S., Jalbert, J., \& Girard, A. (2006). Does preschool enrichment of precursors to arithmetic influence intuitive knowledge of number in low income children? Early Childhood Education Journal, 34(2), 133-146.

Poland, M., Van Oers, B., \& Terwel, J. (2009). Schematising activities in early childhood education. Educational Research and Evaluation,15(3), 305-321.

Sancak, Ö. (2003). Okul öncesi eğitim kurumlarına devam eden 6 yaş çocuklarına sayı ve şekil kavramlarının kazandırılmasında bilgisayar destekli ĕgitim ile geleneksel ĕgitim yöntemlerinin karşılaştırılması (Yayımlanmamış yüksek lisans tezi). Gazi Üniversitesi, Ankara.

Starkey, P., \& Klein, A. (2000). Fostering parental support for children's mathematical development: An intervention with Head Start families. Early Education \& Development, 11(5), 659-680.

Starkey, P., Klein, A., \& Wakeley, A. (2004). Enhancing young children's mathematical knowledge through a pre-kindergarten mathematics intervention. Early Childhood Research Quarterly,19(1), 99-120.

Sophian, C. (2004). Mathematics for the future: Developing a Head Start curriculum to support mathematics learning. Early Childhood Research Quarterly, 19(1), 59-81.

Türkmenoğlu, F. (2005). 60-72 Aylık çocukların matematik becerilerini kazanmalarında, "oyun yoluyla matematik becerilerini kazandirma programı" nın etkisinin incelenmesi (Yayımlanmamış yüksek lisans tezi). Gazi Üniversitesi, Ankara.

Van Den Heuvel-Panhuizen, M., Van Den Boogaard, S., \& Doig, B. (2009). Picture boks stimulate the learning of mathematics. Australasian Journal of Early Childhood, 34(2), 341-373.

Van De Rijt, B. A. M., \& Van Luit, J. E. H. (1998). Effectiveness of the additional early mathematics program for teaching children earlymathematics. Instructional Science, 26, 337-358.

Warren, E., \& Devries, E. (2009). Young Australian indigenous students' engagement with numeracy: Actions that assist to bridge the gap. Australian Journal of Education, 53(2), 159-175.

Yılmaz-Bolat, E., \& Dikici-Sığırtmaç, A. (2006). Sayı ve işlem kavramı kazanımında müzikli oyunların etkisi. Ege Ë̆itim Dergisi, 7(2), 43-56.

Young, J., \& Loveridge, M. (2004). Effects on early numeracy of a program using number books and games. Early Childhood Research Quarterly, 19, 2-98. 